\title{
REDACTIONEEL
}

\section{Een snel oprukkend virus}

\author{
Mr. dr. M.C. Ploem ${ }^{*}$
}

Eind 2019 dook er in China een onbekende ziekteverwekker op: COVID-19, beter bekend als het coronavirus. Het virus, vermoedelijk door de vleermuis op de mens overgedragen, beheerst nu al maanden het nieuws en inmiddels ook ons dagelijks leven. Het gaat bij corona in beginsel om gewone verkoudheids- en griepklachten, maar die kunnen overgaan in een longontsteking die - in uitzonderingsgevallen - met name bij ouderen tot de dood kan leiden. ${ }^{1}$ Medio maart 2020 is er wereldwijd bij ruim 200.000 mensen een corona-infectie vastgesteld waarvan ruim 82.000 patiënten zijn hersteld en waaraan er zo'n 8000 zijn overleden. ${ }^{2}$ Vergeleken met landen waar het virus zeer fors heeft toegeslagen, zoals China en Italië, lijken de problemen in ons land - op het moment van schrijven - nog beheersbaar, maar de vraag is wel of dat zo blijft. Begin maart adviseerde het RIVM mensen die mogelijk met corona geïnfecteerd zijn - huisgenoten van patiënten met COVID-19 en mensen die in risicogebieden zijn geweest en klachten hebben - niet naar hun werk, school of opleiding te gaan, geen fysiek contact te hebben met anderen en als ze naar buiten gaan, op afstand van andere mensen te blijven (intussen zijn deze adviezen echter al verder aangescherpt). Ook werkgevers treffen maatregelen, waarbij vele zich aan de RIVM-richtlijn houden, maar sommigen verder gaan of een iets soepeler beleid voeren. Van bovengenoemde maatregelen gaat vooralsnog geen dwang uit (het zijn instructies), maar gesteld dat de situatie daartoe aanleiding zou geven, tot welke vormen van dwang is de overheid dan bevoegd? En de werkgever: in hoeverre heeft die ruimte om dwang op zijn werknemers uit te oefenen?

Overheidsingrijpen bij besmettelijke ziekten is geregeld in de Wet publieke gezondheid (Wpg), die beoogt een evenwicht te vinden tussen de grondrechten van het individu (op privacy en fysieke integriteit) en de plicht van de overheid om de gezondheid van burgers te beschermen. Om bij de bestrijding van een potentieel zeer gevaarlijk virus het gehele arsenaal van maatregelen uit de kast te kunnen halen en daarover als centrale overheid de regie te kunnen voeren, moet de minister van VWS die ziekte eerst (via een op art. 20 Wpg gebaseerde ministeriële regeling) als een zogenoemde groep A-infectieziekte aanwijzen. ${ }^{3}$ Dat laatste is mogelijk als 'het belang van de volksgezondheid dat vordert en [het] in over-

* $\quad$ Corrette Ploem is onderzoeker en docent gezondheidsrecht bij Amsterdam UMC en redacteur van dit tijdschrift.

1 Het wereldwijde overlijdensrisico werd op 3 maart 2020 door de WHO geschat op 3,4\%, maar kan lager liggen omdat de berekening is gebaseerd op het aantal gerapporteerde besmettingen. Vgl. het overlijdensrisico bij SARS: 9,6\%. Het risico om aan griep te overlijden is kleiner dan 1\%. Zie www.worldometers.info/ coronavirus/ (geraadpleegd op 18 maart 2020).

2 Idem.

3 Daartoe behoorden, voordat het coronavirus zich aandiende, het Middle East respiratory syndrome (MERS$\mathrm{CoV})$, pokken, polio, severe acute respiratory syndrome (SARS) en virale hemorragische koorts. 
eenstemming [is] met het gevoelen van de ministerraad' (bij corona is dit op 28 januari 2020 gebeurd). ${ }^{4}$ Er treedt dan, mogelijk met onmiddellijke ingang, een meldingsplicht in werking waardoor iedere vastgestelde besmetting onverwijld aan de GGD moet worden doorgegeven, die daarvan vervolgens melding maakt bij het RIVM (zie par. $2 \mathrm{Wpg}$ ). Maar dit is natuurlijk niet de 'dwang' waarop ik zojuist doelde. Veel verder gaat de bevoegdheid van de burgemeester (of voorzitter van een veiligheidsregio) om - als een burger zich niet aan de gestelde voorzorgsmaatregelen houdt of medewerking aan medisch onderzoek weigert - te gelasten deze persoon gedwongen in een ziekenhuis ter isolatie op te nemen of door een arts (in het lichaam) te laten onderzoeken (art. $31 \mathrm{Wpg}$ ). Deze fors op de individuele vrijheid van burgers ingrijpende maatregel moet, zo volgt uit de Wpg, wel het laatste redmiddel zijn en mag alleen worden gecontinueerd nadat de rechter daartoe, de betrokkene (op afstand) gehoord hebbende, heeft beslist. De overheid kan (wederom via de burgemeester of voorzitter van de veiligheidsregio) echter ook grijpen naar instrumenten die het bredere maatschappelijke leven raken. Zie in dit verband de artikelen 47 en verder Wpg die de bevoegdheid regelen om terreinen, gebouwen, vervoermiddelen of goederen wanneer ernstig gevaar voor de volksgezondheid dreigt op besmetting te doen onderzoeken en/of te sluiten. Overtreding van laatstgenoemde maatregelen kan burgers op strafrechtelijke sancties komen te staan (art. 67 Wpg).

En de werkgever: waartoe kan die zijn werknemers desnoods dwingen? ${ }^{5}$ In dit verband valt in de eerste plaats te wijzen op de Arbeidsomstandighedenwet (Arbowet), in het bijzonder artikel 11, dat bepaalt dat de werknemer '(...) in zijn doen en laten op de arbeidsplaats, overeenkomstig zijn opleiding en de door de werkgever gegeven instructies, naar vermogen [dient] zorg te dragen voor zijn eigen veiligheid en gezondheid en die van de andere betrokken personen'. In zijn advies 'Werknemers en infectieziekten' uit 2014 concludeerde de Gezondheidsraad echter dat uit deze plicht in elk geval geen vaccinatieplicht voor werknemers volgt: '(...) de werknemer moet wel goed over voor- en nadelen geïnformeerd worden, maar van moeten dulden is geen sprake. De overheid heeft vaccinatie niet algemeen verplicht willen stellen, noch een vaccinatie-eis willen invoeren voor bepaalde beroepsgroepen, noch aan het niet gevaccineerd zijn consequenties willen verbinden'. ${ }^{6}$ Anderzijds biedt de Arbowet via artikel 16, lid 3 en lid 5 wel de mogelijkheid om bij algemene maatregel van bestuur het ondergaan van arbeidsgezondheidskundig onderzoek verplicht te stellen als voorwaarde voor het mogen verrichten van bepaalde arbeid. Maar die voorziening biedt in de situatie van een snel oprukkend virus, waarbij haast geboden is, naar mag worden aangenomen geen reële mogelijkheden voor de werkgever.

4 Zie 'Regeling van de Minister voor Medische Zorg van 28 januari 2020', kenmerk 1643096-201442-PG, ex artikel 20 van de Wet publieke gezondheid (Regeling 2019-nCoV), Stcrt. 2020, 6800.

5 Zo bepaalde een ziekenhuis begin maart dat - niet alleen om besmettingsgevaar in verband met corona te voorkomen, maar ook om de continuïteit van de bedrijfsvoering te garanderen - vanuit de instelling georganiseerde groepsreizen, zoals een skivakantie, tijdelijk niet waren toegestaan. Op 17 maart 2020 adviseerde het Ministerie van Buitenlandse Zaken helemaal geen reizen naar het buitenland te maken, tenzij dat strikt noodzakelijk is.

6 Gezondheidsraad, Werknemers en infectieziekten. Criteria voor vaccinatie, Den Haag: GR 2014, p. 28. Zie in vergelijkbare zin een recent rapport van onderzoeksorganisatie Ecorys, Verplichting griepvaccinatie bij zorgwerkers: wenselijk en mogelijk? Eindrapportage, Rotterdam: Ecorys 2019, p. 4. 
En het privaatrecht: biedt dat dan mogelijk nog soelaas? De arbeidsovereenkomst als zodanig biedt in elk geval geen grond om werknemers rechtstreeks tot handelen te verplichten dat inbreuk maakt op hun persoonlijke levenssfeer of lichamelijke integriteit - zoals thuisblijven, medisch onderzoek of reisrestricties. ${ }^{7}$ Kan dat laatste echter wel indirect worden afgedwongen, door aan niet-naleving van instructies, zoals nu bij het coronavirus, consequenties te verbinden? In het eerdergenoemde Gezondheidsraad-advies wordt in dat verband vooral gewezen op het uitgangspunt binnen het arbeidsrecht dat niet alleen de werkgever zich als 'goed werkgever' moet gedragen (door bijvoorbeeld bij een gevaarlijk virus instructies ter voorkoming van besmetting te geven), maar dat datzelfde ook van de werknemer mag worden verwacht, dat wil zeggen zich gedragen als 'goed werknemer'. Dit betekent, aldus de Raad, dat '(...) hij in de arbeidsrelatie met de werkgever rekening moet houden met diens gerechtvaardigde belangen. Als hetgeen de werkgever verlangt redelijk is en er bij het geven van de opdracht sprake is van een zorgvuldige beslissing, dan zal de werknemer zich daaraan niet zonder goede redenen kunnen onttrekken. Voor niet-meewerken is een rechtvaardiging nodig die, gelet op de in het geding zijnde belangen, als voldoende kan gelden.'

Hieruit is echter nog niet een-twee-drie af te leiden welke consequenties de werkgever mag verbinden aan werknemers die zich niet aan zijn instructies (willen) houden. Zou dit onder omstandigheden grond voor arbeidsrechtelijke consequenties, in het uiterste geval ontslag, kunnen zijn? De Nederlandse rechter heeft zich bij mijn weten nog nooit over zo'n casus gebogen, maar als het zover zou komen, lijkt mij dat niet voorbij kan worden gegaan aan hetgeen in de Wpg over gedwongen isolatie en medisch onderzoek bij personen is bepaald. De kern van die regels is dat verplicht te stellen maatregelen steeds nodig en effectief moeten zijn om ernstig gevaar voor de volksgezondheid (in het bijzonder de gezondheid van werknemers en derden in hun directe omgeving) tegen te gaan. ${ }^{9}$ Hieraan zou echter nog moeten worden toegevoegd dat de instructies aan werknemers niet disproportioneel mogen zijn. 